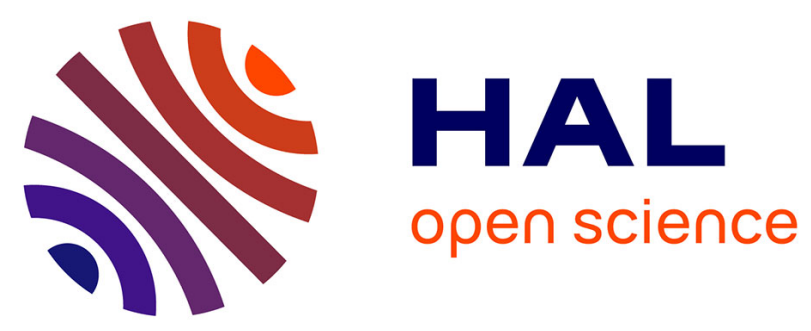

\title{
Statistical design of in silico experiments for the robustness analysis of electrophysiologic response simulators
}

Romain Duponnois, Théo Docquier, Thomas Aiguier, Thierry Bastogne

\section{To cite this version:}

Romain Duponnois, Théo Docquier, Thomas Aiguier, Thierry Bastogne. Statistical design of in silico experiments for the robustness analysis of electrophysiologic response simulators. Safety Pharmacology Society 2017 Annual Meeting, SPS 2017, Dec 2017, Berlin, Germany. hal-01669909

\section{HAL Id: hal-01669909 \\ https://hal.science/hal-01669909}

Submitted on 21 Dec 2017

HAL is a multi-disciplinary open access archive for the deposit and dissemination of scientific research documents, whether they are published or not. The documents may come from teaching and research institutions in France or abroad, or from public or private research centers.
L'archive ouverte pluridisciplinaire HAL, est destinée au dépôt et à la diffusion de documents scientifiques de niveau recherche, publiés ou non, émanant des établissements d'enseignement et de recherche français ou étrangers, des laboratoires publics ou privés. 


\section{Statistical Design of in silico Experiments for the Robustness Analysis of Electrophysiologic Response Simulators. \\ R. DUPONNOIS', T. DOCQUIER', T. AIGUIER', T. BASTOGNE'1,2,3 \\ 'CRAN, ${ }^{1}$ INRIA BIGS, ${ }^{3}$ CYBERnano}

Background. To assess the risk of Torsade de Pointes, the CiPA initiative has proposed to test in silico models able to reconstruct electrophysiologic responses and analyze mechanistic causes of specific toxicological events such as TdP. One example of such simulators is the O'Hara Rudy's model [1], used herein as a benchmark model.

\section{Objectives}

Such in silico models are composed of a large number of biological parameters. Their values are never fully known and they are generally estimated with a substantial uncertainty. So, what happens if the values of some parameters are wrong? Can we still trust the simulated responses? In this application context, our objective is to firstly identify the critical modeling parameters.

\section{Methods}

To reduce the computation time, we propose a statistical approach suited to the screening of model parameters. Our approach relies on a Placket-Burman design of numerical assays. 79 models parameters have been tested and only 80 numerical experiments were carried out. The action potential response was split up into five phases and three statistics (duration, AUC and amplitude) were computed for each phase. Accordingly, 15 response variables were analyzed. A Pareto analysis is finally used to rank the most critical parameters.

\section{Results}

Results show that all the tested modeling factors have the same order of effect on the global response. In other terms, no parameter can be neglected. Two parameters appear as more critical than the other ones: the stimulus current and the initial temperature of the cell. The effects of all the parameters on each of the five beating phase are also estimated and ranked.

\section{Conclusion}

This study analyzes the sensitivity of the simulated potential action response with respect to uncertainty on 79 modeling parameters. All of them have significant effects on at least one part of the response, which emphasizes the relevance to accurately estimate them to trust simulations. As a consequence, another crucial question is worth asking and deals with the model identifiability, i.e. the possibility to learn the true values of the model parameters after obtaining an infinite (theoretical identifiability) or a finite (practical identifiability) number of in vitro observations [1]

[1] T. O'Hara, L Virág, A Varró, and Y, Rudy, Simulation of the undiseased human cardiac ventricular action potential: Model formulation and experimental validation, PLOS Computational Biology, vol. 7, pp. 1-29, 052011.

[2] S. Dobre, T. Bastogne, C. Profeta, M. Barberi-Heyob, and A. Richard, "Limits of variance-based sensitivity analysis for non-identifiability testing in high dimensional dynamic models," Automatica, vol. 48, pp. 2740-2749, Aug. 2012.

\begin{tabular}{|c|c|c|c|c|c|c|c|}
\hline \multicolumn{8}{|c|}{ Factors } \\
\hline & $f_{1}$ & $f_{2}$ & 3 & $\mathrm{f}_{4}$ & $f_{5}$ & $f_{6}$ & $f_{7}$ \\
\hline 1 & 1 & 1 & 1 & -1 & 1 & -1 & -1 \\
\hline 2 & -1 & 1 & 1 & 1 & -1 & 1 & -1 \\
\hline 3| & -1 & -1 & 1 & 1 & 1 & -1 & 1 \\
\hline 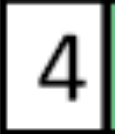 & 1 & -1 & -1 & 1 & 1 & -1 & -1 \\
\hline 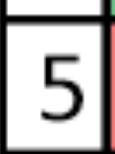 & -1 & 1 & -1 & -1 & $\overline{1}$ & 1 & 1 \\
\hline 6 & 1 & -1 & 1 & -1 & -1 & 1 & 1 \\
\hline 1 & 1 & 1 & -1 & 1 & -1 & -1 & 1 \\
\hline & & -1 & -1 & -1 & -1 & -11 & \\
\hline
\end{tabular}

Fig. 1: Example of Plackett-Burman design of experiments used to identify the most critical modeling parameters of the O'Hara-Rudy's model [1]. 80 simulations (tests) were carried out on Matlab TM to estimate the additive effects of 79 model parameters (factors). Each of them took 2 values: $\pm 10 \%$ nominal values.

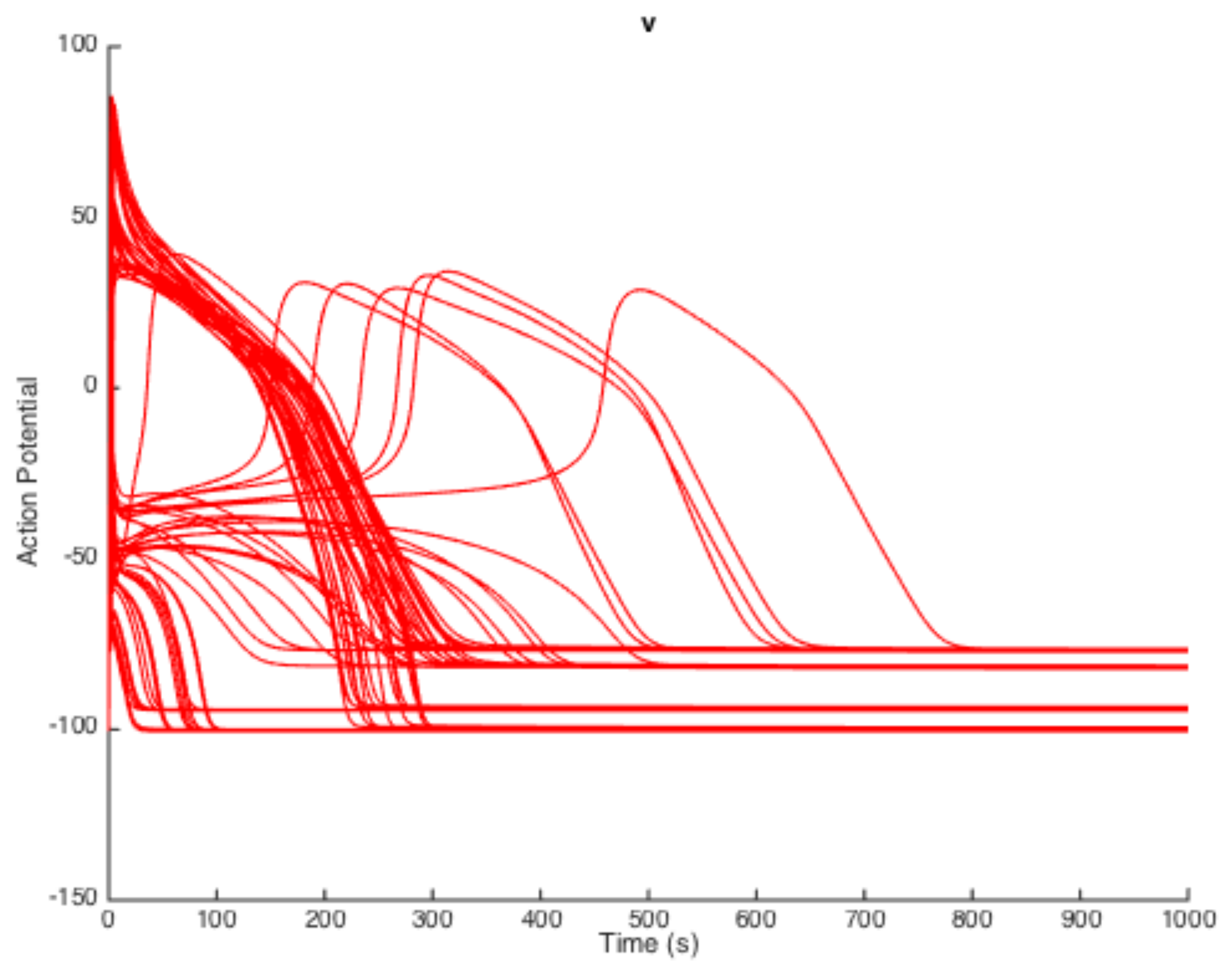

Fig.2: Superposition of simulated action potential responses provided by the O'Hara-Rudy's model [1].

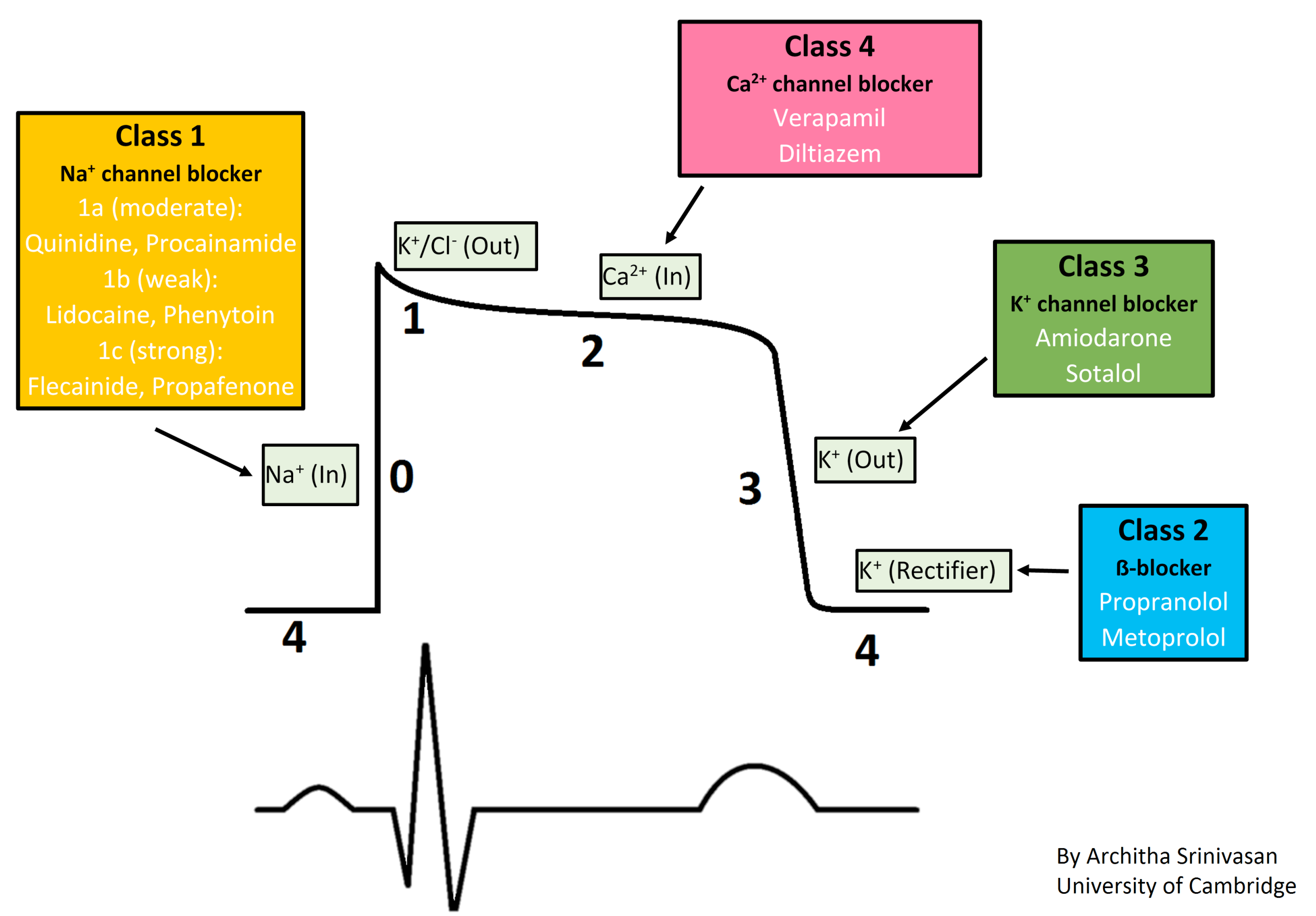

Fig.3: Each response is split up by an algorithm into 5 phases $(0,1,2,3,4)$ and 4 statistics: duration, AUC, min \& max values are computed

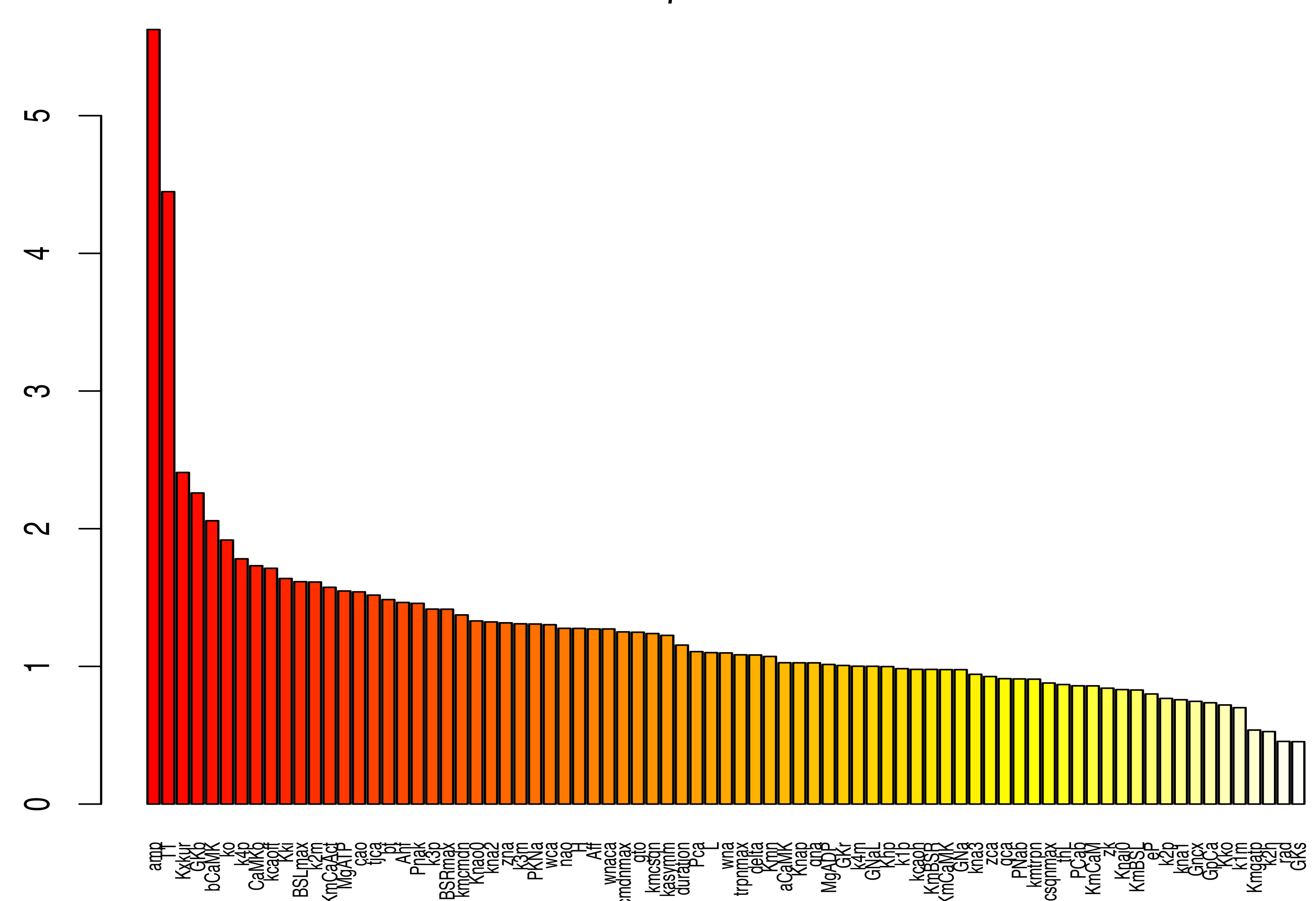

Fig.4: Pareto's Diagram of the model parameters and their effect on the AUC of the complete action potential response 